\title{
Horned Grebe Podiceps auritus and Red-necked Grebe Podiceps grisegena in Sweden 2011 - results from a national survey
}

\author{
Svarthakedopping Podiceps auritus och gråhakedopping Podiceps grisegena $i$ \\ Sverige 2011 - resultat från en nationell inventering
}

\author{
GABRIEL NOREVIK
}

\begin{abstract}
The breeding populations of Horned Grebe Podiceps auritus and Red-necked Grebe Podiceps grisegena were surveyed in Sweden 2011. The estimate for Horned Grebe was 2000 pairs, an increase from about 1200 pairs in 1996 towards the estimate of 2200 pairs in 1972. The estimate for Red-necked Grebe was 1300 pairs and the population size has most certainly increased in the last decades. Habitat use among the breeding birds differed between species and region. In south Sweden, both species were most commonly found in artificial water bodies, and a recent increase in the numbers of such waters may have contributed to the population increases. In north

Sweden the species were mainly found in natural inland water bodies or along the Baltic coast. Similar long-term population trends were also seen in a long-term observational dataset of passage birds from Ottenby Bird Observatory in southeast Sweden. There was no obvious effect of the coldness at their wintering grounds on the amount of birds seen at Ottenby the following year, but indirect effects of winter harshness cannot be ruled out.

Gabriel Norevik, Department of Biology, Evolutionary Ecology, Lund University, Ecology Building, S-223 62 Lund, Sweden.gabriel.norevik@biol.lu.se
\end{abstract}

Received 7 April 2014, Accepted 27 October 2014, Editor: Å. Lindström

\section{Introduction}

For conservation purposes it is important to track the status and trend of a given population. Trends can be estimated when the size of the population is regularly estimated (Sutherland 2006). A common approach for bird population monitoring is to take repeatable sample measurements, either in the breeding areas (e.g. line transects or point counts), along the migratory pathway (e.g. standardized ringing or observation schemes), or during winter for birds forming dense flocks (e.g. counting numbers: Bibby et al. 2000). Breeding bird censuses are per definition spatially linked to a certain region, which is a great advantage when monitoring a local population. But surveying a breeding species over a vast area is often demanding and costly. Observation schemes along the migratory pathway are relatively cheap and can therefore be carried out regularly, and a relative measure of the amount of birds passing can be summarized on a yearly basis. The apparent weakness with this method is that the population size and the true distribution of the birds counted rarely are known.

Two sparsely occurring bird species in Sweden are the Horned Grebe Podiceps auritus and the
Red-necked Grebe Podiceps grisegena. Due to the low population numbers and stratified breeding distributions of the two species, the general techniques used in bird monitoring in Sweden are not sufficient for trend and population size estimates (Bibby et al. 2000, Lindström \& Green 2013). The Swedish Ornithological Society therefore announced Horned Grebe and Red-necked Grebe to be subjects of a national survey during the breeding season of 2011, and urged each local birding community to contribute with observations. In contrast to the Red-necked Grebe, the Horned Grebe has been surveyed before. The first time was in 1972, when the population was estimated at 2200 pairs and then again in 1996, when the results suggested a drop in the Swedish population to 1200 pairs (Regnell 1981b, Douhan 1998).

The aims of this paper are to describe the implementation of the survey throughout the country, to summarize the results from the individual provinces, and to give an estimate of the current status of the two species in Sweden. Furthermore, the data on habitat choices of breeding birds are presented. In addition, the results from this survey and previous surveys are accompanied with long-term 
observational data from Ottenby Bird Observatory, in an attempt to estimate current population trends of these two secretive Swedish breeders. Finally, winter harshness and recent Swedish wetland establishments, two factors suggested to influence population size of the two grebe species through winter survival and breeding success, are discussed and evaluated.

\section{Study species}

Horned Grebe and Red-necked Grebe are two medium-sized diving birds that prefer smaller water-bodies such as shallow lakes and reservoirs (del Hoyo et al. 1992). The Horned Grebe mainly breeds in moderate-sized eutrophic lakes and pools in the boreal region of the Holarctic. The Red-necked Grebe has a more southerly distribution, with a higher preference for lowland basins of on average larger sizes (Cramp \& Simmons 1977, Fjeldså 2004). Their winter distributions are largely over-lapping in Europe. They stretch from western Scandinavia and the North Sea to the Mediterranean basin (Gilissen et al. 2002, SOF 2002, Fjeldså 2004). However, there are relatively more Red-necked Grebes found in Danish waters (Jensen 1993, Stone et al. 1995), and recently a large winter population of Horned Grebes was discovered in the Pomeranian Bight in the southern Baltic Sea (Durinck et al. 1994, Sonntag et al. 2009 and references therein). A Horned Grebe ringed in the province of Östergötland and found in The Netherlands is the only link between the Swedish breeding population and their presumed winter distribution (Fransson et al. 2001), but two Finnish ringed Horned Grebes were found in Poland and France (Saurola et al. 2013). Three recoveries of Red-necked Grebe tie Denmark winter birds and Finland summer population together, and one Rednecked Grebe ringed in southern Germany was found breeding in Denmark (Bønløkke et al. 2006, Saurola et al. 2013). The breeding range of the two species in Sweden overlaps greatly in the southeastern and north-eastern part of the country, and in the south they are increasingly occurring in the same type of man-made habitats (Axelsson 1997, Douhan 1998, SOF 2002). Despite decreasing global population numbers (BirdLife International 2013), the two species are listed as "Least concern" on the IUCN Red List for birds (IUCN 2012). In Sweden, both species seem to have increased in recent decades (Regnell 1981b, Grenmyr 1984, Axelsson 1997, Douhan 1998, Olsson \& Wiklund 1999, Hedberg Fält 2012, Ottosson et al. 2012).

\section{Method}

\section{National survey}

Prior to the breeding season of 2011, an invitation was sent to the regional birding communities throughout Sweden to participate in a nation-wide survey, to encourage birders to contribute with details of observed grebes to the local report committees, which regionally summarized the information. To facilitate reporting and compilation, the local report committees were provided with protocols and methodological guidelines for the survey. Water bodies potentially harbouring breeding grebes should be surveyed for birds at least once during the breeding season. If there were any uncertainties in the assessment of breeding birds after the initial visit, a second visit was proposed. To keep concordance with the national surveys on Horned Grebe in 1972 and 1996, displaying birds or territory holding birds were counted as breeding attempts (Regnell 1981b, Douhan 1998). This followed the methodological recommendations by Regnell (1981a), in order to increase the efficiency of the survey while reducing the risk of disturbing breeding birds. To streamline the survey, a first visit was suggested to be carried out in the period when all birds were assumed to have arrived at the local area, but before the first birds had started incubation. Depending on when lakes became icefree, suitable dates varied considerably between different parts of the country.

The compiled survey results were obtained from the local report committees together with information of the scope in which the survey had been carried out. These results were here arranged in three categories depending on the regional survey scope. Category A: Areas where the surveys had been conducted according to the guidelines, or in a way resulting in an almost complete coverage of presumed breeding areas. Category B: Regions that were less thoroughly surveyed, but where population estimates could be based on recent surveys, or proper knowledge of the breeding grebes. Category $\mathrm{C}$ : Regions where the numerical estimates of the populations were less well substantiated, or where no survey had been carried out at all. In these cases, estimates were based on spontaneous reports to the local report committee, information from earlier years, population numbers in neighbouring regions, and for Horned Grebe, results from prior national surveys that were extrapolated to a rough size estimate of the populations of 2011. Numbers in category $\mathrm{C}$ are hence accompanied with a large uncertainty 
and should be treated carefully. Surveys based on few visits like here can give an underestimation of the number on breeding grebes in the range of 20-60 $\%$ (Regnell 1981a). Therefore, the observed number of breeding pairs has in each province been presented together with an estimate of the true number of breeders. The uncertainty in the estimation varies with the coverage of the survey $(\mathrm{A}-\mathrm{C})$, which serves as the measure when the accuracy of the observed number $(\operatorname{good}=* * *-$ poor $=*$ ) was estimated. To facilitate the comparison with prior national surveys of Horned Grebe the results have been presented per province, which only in a few cases were fully synonymous to the regions defined by the local report committees. Thus, in some cases the provincial numbers have been based on information from more than one regional survey. While discussing the Swedish populations of the two species in a general sense, the broader definition "region" has been used. The Swedish provinces are traditionally organized into the three regions Götaland, Svealand and Norrland (Figure 1).

\section{Breeding habitat}

Along with survey data on the breeding grebes, the birds' choice of habitat was also recorded. To avoid interference with the time and effort put on observing the birds, the surveyor was instructed to just briefly describe the water body hosting the breeding grebes (e.g. eutrophic lake, wetland, irrigation pond etc.). This information has been thoroughly reported from Gotland, Östergötland and the eastern part of Småland through the survey protocols. Data from Skåne, Värmland, Dalarna, parts of Södermanland and Uppland, Gästrikland, Medelpad and Hälsingland have been presented in alternative ways. For the other provinces, this information has been retrieved from Artdatabanken (2013). Water bodies with breeding grebes were categorized in four general groups based on descriptive information gathered from Artdatabanken (2013) or with help from the local report committees. These groups were then used to illustrate the habitat choice of the breeding grebes throughout the country. The four groups were defined as follows:

Natural inland water bodies: This group consists of water bodies not directly or deliberately influenced by humans, as for example lowland basins and woodland lakes, tarns and natural pools.

Artificial water bodies: Newly established irrigation ponds and small wetlands on golf courses belong to this group. There are also thoroughly managed wetlands found in this category, as well as

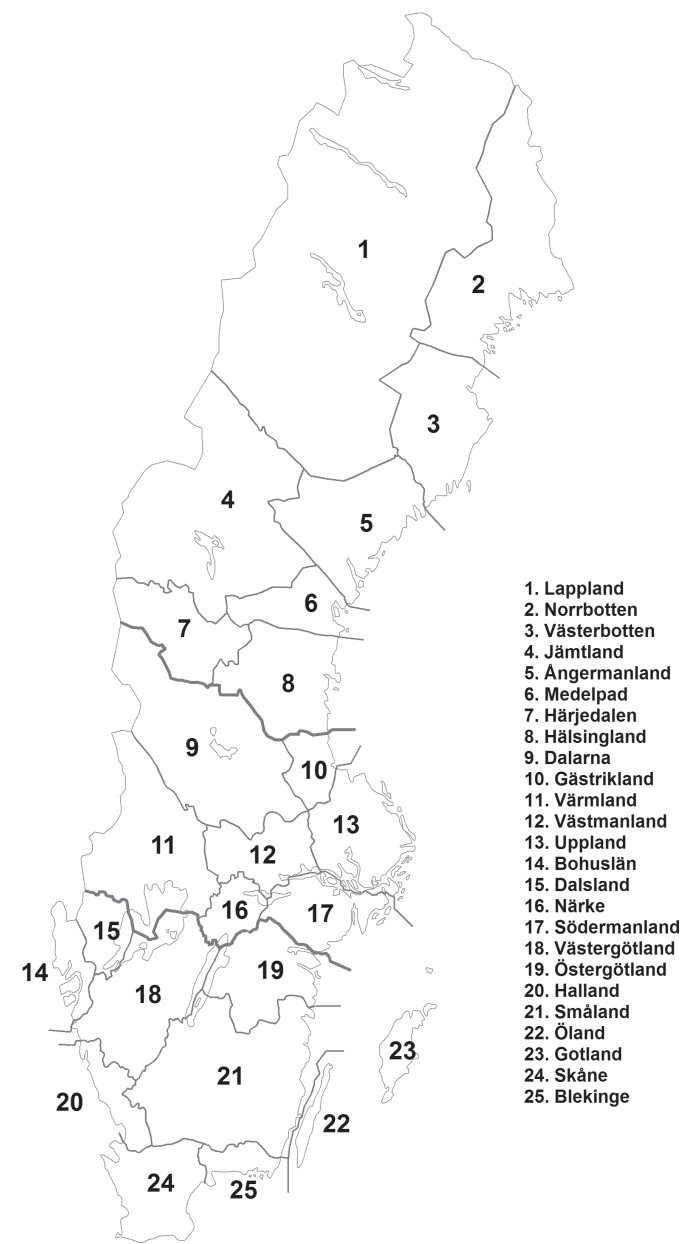

Figure 1. The geographical distribution of the Swedish provinces, with bold lines separating the three regions where Götaland is in the south, Svealand in central Sweden and Norrland in the north.

Den geografiska fördelningen av de svenska landskapen med fetare linjer som avskiljer Götaland, Svealand och Norrland.

restored wetlands, which retain their attractiveness through repeated human efforts. The well-known Lake Hornborga and Lake Tåkern are two examples of lowland basins that have received extensive actions to retain current appearance (Naturvårdsverket 1997). They both belong to this group.

Coast: Breeders found in bays and around islets along the coast of the Baltic Sea are included in this group. In some cases birds breeding in outlets of larger rivers have been included here as well (see below), since the border between the habitat groups is not easy to resolve. 
Others: Single breeding pairs found in other habitats than the above mentioned have been placed in this group together with observations made in habitats intermediate to the descriptions above.

Regional and interspecific differences in habitat use were evaluated with chi-square tests. $\mathrm{R}$ version 3.0.0. was used in the statistical analysis ( $\mathrm{R}$ Core Team 2013).

\section{Long-term observation data}

Ottenby, at the southern tip of the Baltic island Öland $\left(56^{\circ} 12^{\prime} \mathrm{N}, 16^{\circ} 24^{\prime} \mathrm{E}\right)$, located off the Swedish southeast coast, is well-known for its richness in both resting and migrating birds (Edelstam 1972). At
Ottenby Bird Observatory, birds have been ringed for almost 70 years (Hjort \& Lindholm 1978). Since 1963 , daily notes of birds observed in the vicinity of the observatory have been taken, alongside the bird observatory's ringing activity. Sight records of Red-necked Grebe and Horned Grebe have been extracted and then summarized on a yearly basis for spring and autumn seasons, respectively. This gives the number of days per season and year that the two species have been observed. The manning of the bird observatory has mainly followed the time schedule of the standardized trapping scheme introduced in 1972, and the same periods have hence set the limit for the counting of spring and autumn observations in this study (Hjort \& Lindholm 1978): these time

Table 1. Reported and estimated numbers of Horned Grebes per Swedish province in 2011. For each province is given the method of data collection (A-C [see method for further info]) and accuracy of the estimate $(*=$ poor, $* *=$ medium, $* * *=$ good). Rapporterade och skattade antal svarthakedoppingar per landskap år 2011. För varje landskap presenteras vilken metod som använts för att få fram uppgifterna (A-C [se metod för ytterligare information]) och precisionen $i$ de skattade antalen (* = dålig, $* *=$ måttlig, $* * *=$ god).

\begin{tabular}{|c|c|c|c|c|c|c|}
\hline $\begin{array}{l}\text { Province } \\
\text { Landskap }\end{array}$ & $\begin{array}{l}\text { Method } \\
\text { Metod }\end{array}$ & $\begin{array}{r}\text { Rep. } \\
\text { Rap. } \\
\text { (n) }\end{array}$ & $\begin{array}{r}\text { Est } \\
\text { Skatt } \\
\text { min } \\
\end{array}$ & $\begin{array}{l}\text { mate } \\
\text { t antal } \\
\max \end{array}$ & $\begin{array}{l}\text { Accuracy } \\
\text { Precision }\end{array}$ & $\begin{array}{l}\text { References } \\
\text { Referenser }\end{array}$ \\
\hline Gästrikland & $\mathrm{B}$ & 142 & 190 & 215 & $* *$ & Aspenberg 2012a \\
\hline Hälsingland & B & 126 & 140 & 160 & $* * *$ & M. Axbrink, pers. comm. \\
\hline Medelpad & $\mathrm{B}$ & 37 & 45 & 55 & $* *$ & P. Helttunen, pers. comm. \\
\hline Härjedalen & $\mathrm{C}$ & 12 & 30 & 50 & $*$ & J. Rågehall, pers. comm. \\
\hline Jämtland & $\mathrm{C}$ & 19 & 100 & 200 & $*$ & G. Storensten, pers. comm. \\
\hline Ångermanland & $\mathrm{C}$ & 60 & 120 & 180 & $*$ & K. Holmqvist, pers. comm.. \\
\hline Västerbotten & $\mathrm{C}$ & 29 & 150 & 220 & $*$ & Sundström \& Olsson 2005; M, Laisfeldt pers. comm. \\
\hline Norrbotten & $\mathrm{C}$ & 15 & 10 & 20 & * & Sundström \& Olsson 2009; R. G. Gustavsson, pers. comm. \\
\hline Lappland & $\mathrm{C}$ & 75 & 50 & 100 & $*$ & H. Rune, pers. comm. \\
\hline Norrland & & & 835 & 1200 & & \\
\hline Närke & $\mathrm{B}$ & 41 & 45 & 55 & $* *$ & L. Johnsson, pers. comm. \\
\hline Södermanland & A & 165 & 210 & 250 & ** & Flodin 2012, M. Åsberg, pers. comm. \\
\hline Uppland & $\mathrm{A}, \mathrm{C}$ & 160 & 210 & 250 & ** & B. Douhan, M. Åsberg, pers. comm. \\
\hline Västmanland & $\mathrm{C}$ & 17 & 25 & 35 & $*$ & T. Pettersson, pers. comm. \\
\hline Värmland & A & 15 & 15 & 20 & $* * *$ & Carlsson 2011 \\
\hline Dalarna & $\mathrm{C}$ & 6 & 15 & 25 & $*$ & U. Grenmyr, pers. comm. \\
\hline Svealand & & & 520 & 635 & & \\
\hline Skåne & A & 0 & 0 & 0 & $* * *$ & Bengtsson 2011 \\
\hline Blekinge & $\mathrm{C}$ & 1 & 1 & 3 & $* *$ & Artdatabanken 2013 \\
\hline Småland & A,B & 62 & 70 & 80 & $* *$ & Johansson 2012, C. Ljungberg, pers. comm. \\
\hline Öland & $\mathrm{B}$ & 22 & 25 & 35 & $* *$ & A. Helseth, pers. comm. \\
\hline Gotland & A & 193 & 210 & 250 & $* * *$ & P. Smitterberg, pers. comm. \\
\hline Halland & - & - & 0 & 0 & & Artdatabanken 2013 \\
\hline Bohuslän & - & - & 0 & 0 & & Artdatabanken 2013 \\
\hline Dalsland & $\mathrm{C}$ & 1 & 1 & 3 & * & Artdatabanken 2013 \\
\hline Västergötland & $\mathrm{B}$ & 54 & 60 & 70 & & P. Hedberg Fält, pers. comm. \\
\hline Östergötland & A & 75 & 90 & 110 & ** & Nygårds 2011 \\
\hline Götaland & & & 457 & 551 & & \\
\hline Total & & & 1812 & 2386 & & \\
\hline
\end{tabular}


spans are 15 Mars - 15 June and 25 July - 15 November, for spring and autumn seasons respectively. Thus, (the few) observations of grebes noted earlier in spring or later in the autumn were not included in the analysis, nor were the small number of observations of the species made during the summer recess of the standardized trapping. The trends in the number of days per year with observations were evaluated with regression analysis. To get the residuals of the material normally distributed, base-10 logarithms of the yearly numbers of observation-days were obtained.

\section{Winter harshness}

A measure of winter harshness in the presumed wintering areas of the Swedish populations of the two grebes was obtained by using mean daily temperature from weather stations in Rotterdam (The Netherlands), Vestervig (Denmark), Falsterbo (Sweden), Rostock (N Germany) and Angermunde (N Germany). A Hellmann index (Ijnsen 1988) was computed for each station following Sauter et al. (2010). This index is the absolute value of the sum of all negative mean daily temperatures between December and February. In the subsequent principal component analysis of the stations' Hellmann indices, the first principal component (PC1) explained $93.3 \%$ of

Table 2. Reported and estimated numbers of Red-necked Grebes per Swedish province in 2011. For each province is given the method of data collection (A-C [see method for further info]) and accuracy of the estimate $(*=$ poor, $* *=$ medium, $* * *=$ good). Rapporterade och skattade antal gråhakedoppingar per landskap år 2011. För varje landskap presenteras vilken metod som använts för att få fram uppgifterna (A-C [se metod för ytterligare information]) och precisionen $i$ de skattade antalen (* = dålig, $* *=$ måttlig, $* * *=\operatorname{god})$.

\begin{tabular}{|c|c|c|c|c|c|c|}
\hline $\begin{array}{l}\text { Province } \\
\text { Landskap }\end{array}$ & $\begin{array}{l}\text { Method } \\
\text { Metod }\end{array}$ & $\begin{array}{r}\text { Rep. } \\
\text { Rap. } \\
\text { (n) }\end{array}$ & $\begin{array}{r}\text { Est } \\
\text { Skatt } \\
\text { min }\end{array}$ & $\begin{array}{l}\text { Imate } \\
\text { at antal } \\
\max \end{array}$ & $\begin{array}{l}\text { Accuracy } \\
\text { Precision }\end{array}$ & $\begin{array}{l}\text { References } \\
\text { Referenser }\end{array}$ \\
\hline Gästrikland & $\mathrm{B}$ & 2 & 2 & 5 & $* *$ & Aspenberg 2012b \\
\hline Hälsingland & $\mathrm{B}$ & 14 & 15 & 25 & $* *$ & M. Axbrink, pers. comm. \\
\hline Medelpad & $\mathrm{B}$ & 2 & 2 & 5 & $* *$ & P. Helttunen, pers. comm. \\
\hline Härjedalen & $\mathrm{C}$ & 0 & 0 & 5 & $*$ & J. Rågehall, pers. comm. \\
\hline Jämtland & $\mathrm{C}$ & 2 & 0 & 10 & $*$ & G. Storensten, pers. comm. \\
\hline Ångermanland & $\mathrm{C}$ & 22 & 40 & 100 & * & K. Holmqvist, pers. comm. \\
\hline Västerbotten & $\mathrm{C}$ & 25 & 200 & 350 & $*$ & Sundström \& Olsson 2005; M, Laisfeldt pers. comm. \\
\hline Norrbotten & $\mathrm{C}$ & 65 & 100 & 200 & * & Sundström \& Olsson 2009; R. G. Gustavsson, pers. comm. \\
\hline Lappland & $\mathrm{C}$ & 75 & 25 & 75 & $*$ & H. Rune, pers. comm. \\
\hline Norrland & & & 384 & 775 & & \\
\hline Närke & $\mathrm{B}$ & 20 & 25 & 30 & $* *$ & L. Johnsson, pers. comm. \\
\hline Södermanland & $\mathrm{C}$ & 3 & 5 & 10 & $*$ & P. Flodin, M. Åsberg, pers. comm. \\
\hline Uppland & $\mathrm{A}, \mathrm{C}$ & 52 & 55 & 65 & ** & B. Douhan, M. Åsberg, pers. comm. \\
\hline Västmanland & $\mathrm{C}$ & 2 & 2 & 5 & $*$ & T. Pettersson, pers. comm. \\
\hline Värmland & $\mathrm{B}$ & 0 & 0 & 2 & ** & Carlsson 2011 \\
\hline Dalarna & $\mathrm{C}$ & 2 & 2 & 5 & $*$ & U. Grenmyr, pers. comm. \\
\hline Svealand & & & 89 & 117 & & \\
\hline Skåne & $\mathrm{A}$ & 250 & 250 & 275 & $* * *$ & Bengtsson 2011 \\
\hline Blekinge & $\mathrm{C}$ & 0 & 0 & 5 & $*$ & Artdatabanken 2013 \\
\hline Småland & $\mathrm{B}$ & 4 & 5 & 10 & $* *$ & Johansson 2012, C. Ljungberg, pers. comm. \\
\hline Öland & $\mathrm{B}$ & 51 & 55 & 65 & $* *$ & A. Helseth, pers. comm. \\
\hline Gotland & A & 71 & 75 & 85 & $* * *$ & P. Smitterberg, pers. comm. \\
\hline Halland & $\mathrm{C}$ & 7 & 10 & 15 & $*$ & Artdatabanken 2013 \\
\hline Bohuslän & - & - & 0 & 0 & & SOF 2002; Artdatabanken 2013 \\
\hline Dalsland & $\mathrm{C}$ & 1 & 1 & 3 & * & Artdatabanken 2013 \\
\hline Västergötland & $\mathrm{C}$ & 188 & 180 & 250 & $*$ & P. Hedberg Fält, pers. comm. \\
\hline Östergötland & $\mathrm{B}$ & 61 & 60 & 80 & $* *$ & Nygårds 2011 \\
\hline Götaland & & & 636 & 788 & & \\
\hline Total & & & 1109 & 1680 & & \\
\hline
\end{tabular}


the variance and was used as an overall measure for winter harshness in Northern Europe. The influence of winter harshness on the number of observationdays of the two grebes at Ottenby in the following year was evaluated with regression analysis.

\section{Result}

\section{National survey}

The Swedish population of Horned Grebe 2011 was estimated to about $2000(1812-2386)$ pairs (Table $1)$. The majority of the $835-1200$ breeding pairs in Norrland were found in the coastal provinces. Unfortunately, only Gästrikland, Hälsingland and Medelpad had been surveyed properly in the region, while the result from the rest of Norrland was less well substantiated. In Svealand the population of Horned Grebes was estimated to 520-635 pairs, while the number in Götaland fell between 457 and 551 pairs. The species was most numerous in the eastern coastal provinces, was scarce to rare further west, and was almost lacking in the south-westernmost provinces.

In total about 1300 (1109-1680) pairs of Rednecked Grebes were estimated in the survey (Table 2 ). The 384-775 pairs in Norrland were estimates mainly based on extrapolations of historical data and should be considered with care when evaluated. The species was a scarce breeder in Svealand and only 89-117 pairs were recorded in the region, where a majority of the birds were found in Uppland. In Götaland the population of Red-necked Grebe was estimated to 636-788 pairs. The distribution in southern Sweden was rather scattered except in Västergötland and Östergötland where the lowland basins Lake Hornborga (175-180 pairs) and Lake Tåkern (about 50 pairs) held a considerable part of the regional population.

\section{Breeding habitat}

The habitat use among the observed grebes differed between the species throughout the country (Götaland: $\chi^{2}(3, \mathrm{~N}=1031)=72.9, \mathrm{p}<0.001$, Svealand: $\chi_{(3, \mathrm{~N}=425)}^{2}=79.23 \mathrm{p}<0.001$, Norrland: $\chi_{(3, \mathrm{~N}=605)}=$ $19.9, \mathrm{p}<0.001)$. Within the two species habitat use differed significantly between the Swedish regions (Horned Grebe: $\chi^{2}{ }_{(6, \mathrm{~N}=1229)}=6886.6, \mathrm{p}<0.001$, Red-necked Grebe: $\left.\chi^{2}(6, \mathrm{~N}=832)=752.6, \mathrm{p}<0.001\right)$. In Götaland, $50 \%$ of the Horned Grebes and $80 \%$ of the Red-necked Grebes were found in artificial water bodies (Figure 2). In Svealand over $50 \%$ of
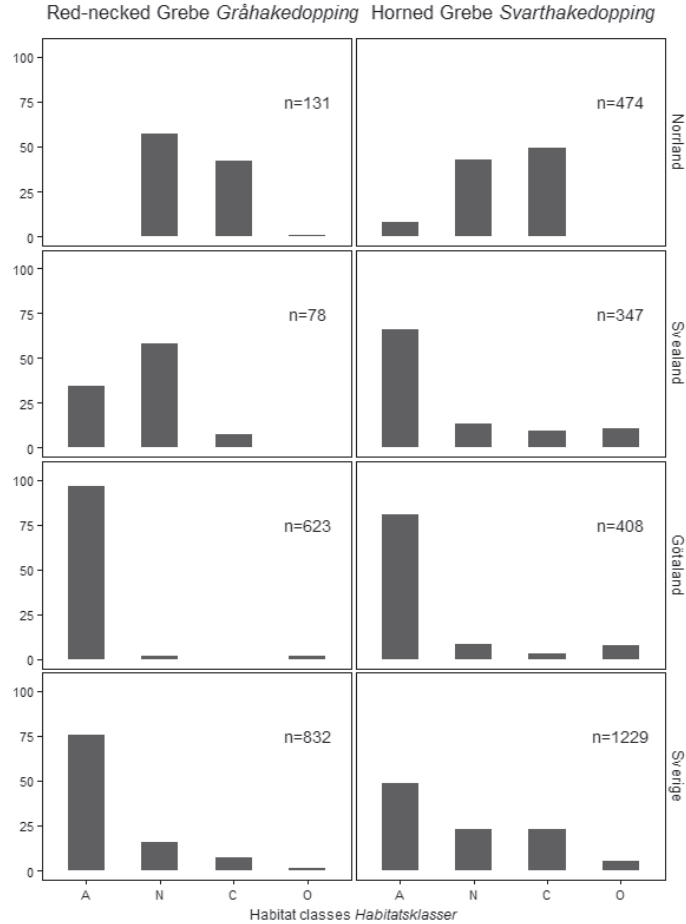

Figure 2. The percentage of Red-necked Grebe (left) and Horned Grebe (right) in artificial water bodies (A), natural inland water bodies $(\mathrm{N})$, coast $(\mathrm{C})$ and in other $(\mathrm{O})$ habitats, in Norrland, Svealand, Götaland and Sweden (Sverige) respectively, with (n) as the number of observed breeding pairs. Note that the data is based on observed birds only, which excludes large quantities of the presumed breeders in Norrland, giving a bias to the habitat selected in the south in the national summary.

Fördelningen (\%) av gråhakedopping (vänster) och svarthakedopping (höger) $i$ konstgjorda inlandsvatten (A), naturliga inlandsvatten $(N)$, kust $(C)$ och övriga (O) habitat $i$ Norrland, Svealand, Götaland och sammanlagt $i$ Sverige med (n) som antal noterade häckningar som räknats. Notera att informationen enbart är baserad på observerade fåglar vilket utesluter en stor andel av de förmodade häckfåglarna i Norrland, och därmed ger en överrepresentation av habitatutnyttjandet hos de sydliga fåglarna i totalsummeringen.

the Red-necked Grebes were registered in natural inland waters, while about $60 \%$ of the Horned Grebes were observed in artificial water bodies. In Norrland the two species were mainly found in coast habitats and natural inland water bodies.

\section{Long-term observation data}

From 1972 to 2012, Horned Grebes were at Ottenby observed on 128 days in spring and 1287 days in autumn (Figure 3 ). The temporal trend was best 


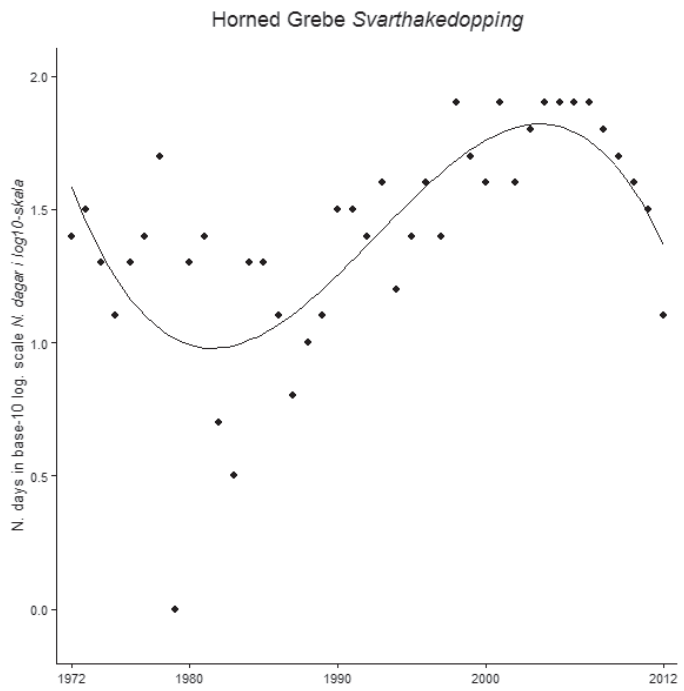

Figure 3. The annual number of days when Horned Grebe was observed at Ottenby between 1972 and 2012 presented in $\log 10$ scale. The line represents a third polynomial regression $\mathrm{t}(37)=-4.74, \mathrm{p}<0.001$, Adj. $\mathrm{R}^{2}=0.51$.

Antalet dagar per år då svarthakedopping har observerats vid Ottenby mellan 1972 och 2012 här presenterat med log10-skala. Linjen representerar ett tredje gradens polynom $t(37)=-4,74, p<0,001$, Adj. $R^{2}=0,51$. described by a third polynomial regression $\left(\mathrm{t}_{(37)}\right.$ $=-4.74, \mathrm{p}<0.001$, Adj. $\left.\mathrm{R}^{2}=0.51\right)$. Whereas the numbers have varied dramatically over the study period, with a low-point in the early 1980s and a peak in the early 2000s, the numbers were very similar at the start and end of the study period. In parallel with the increase of observations from the 1990s and onwards, in recent years Horned Grebes were more commonly observed in the early part of autumn than before (Figure 4 and 5).

The occurrence pattern of Red-necked Grebe at Ottenby showed a positive trend throughout the study period (linear regression $\mathrm{t}_{(39)}=7.47, \mathrm{p}$ $<0.001$, Adj. $\mathrm{R}^{2}=0.58$, Figure 6). Until the mid1990s, Red-necked Grebes were barely seen in the springs and the majority of the 392 observation days in the season were from the second half of the study period (Figure 7). A similar pattern was found among the 1089 days with observations in autumns (Figure 8). From the late 1990s and onwards the species has been more commonly seen in the early part of the autumn.

\section{Winter harshness}

No significant relationship was found between the yearly variation in winter weather in Northern Eu-

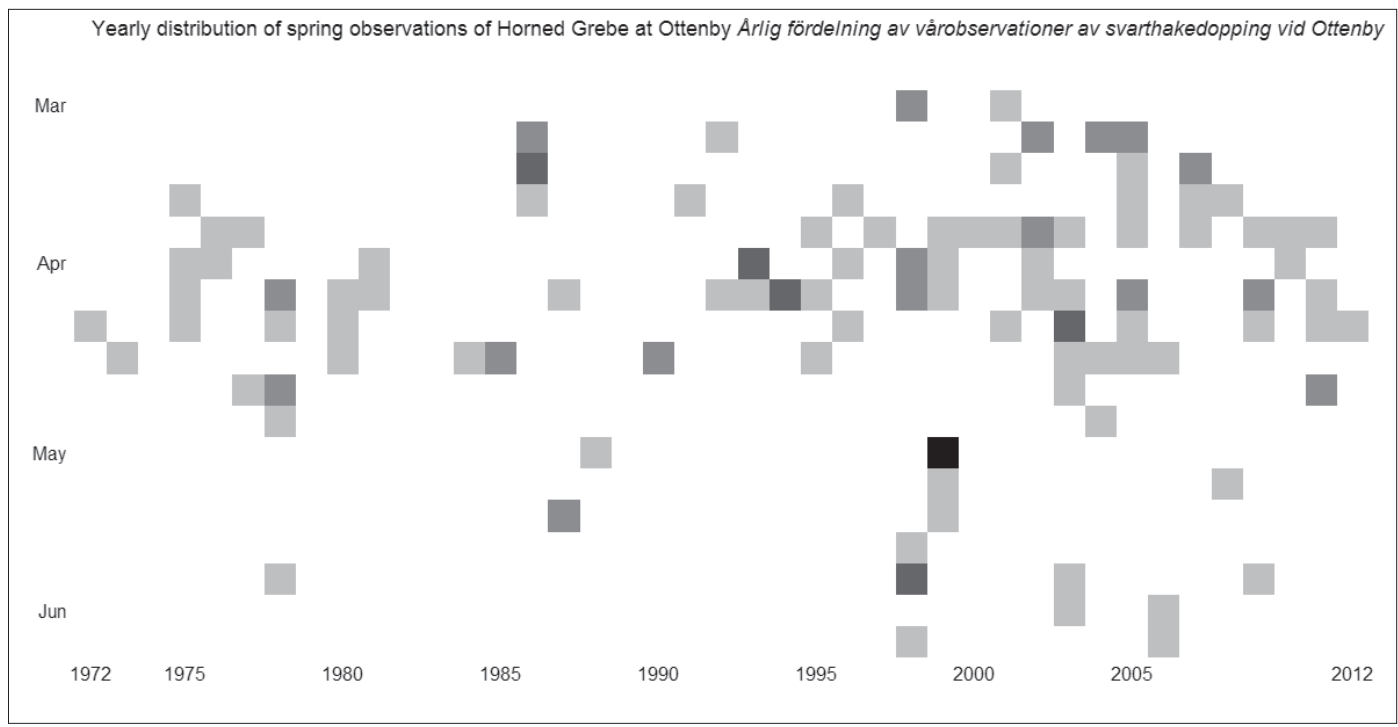

Figure 4. Schematic presentation of days with observations of Horned Grebe at Ottenby in springs 1972 to 2012 . Each square represents a five-day period between 15 Mars - 15 June and the six different colours (white to black) illustrate the number of days (0-5) with observations for each five-day period.

En schematisk presentation av dagar med observationer av svarthakedoppingar vid Ottenby under vårarna 1972 till 2012 . Varje ruta representerar en femdagarsperiod mellan 15 mars - 15 juni och de sex olika färgerna (vitt till svart) illustrerar antalet dagar (0-5) med observationer för varje femdagarsperiod. 


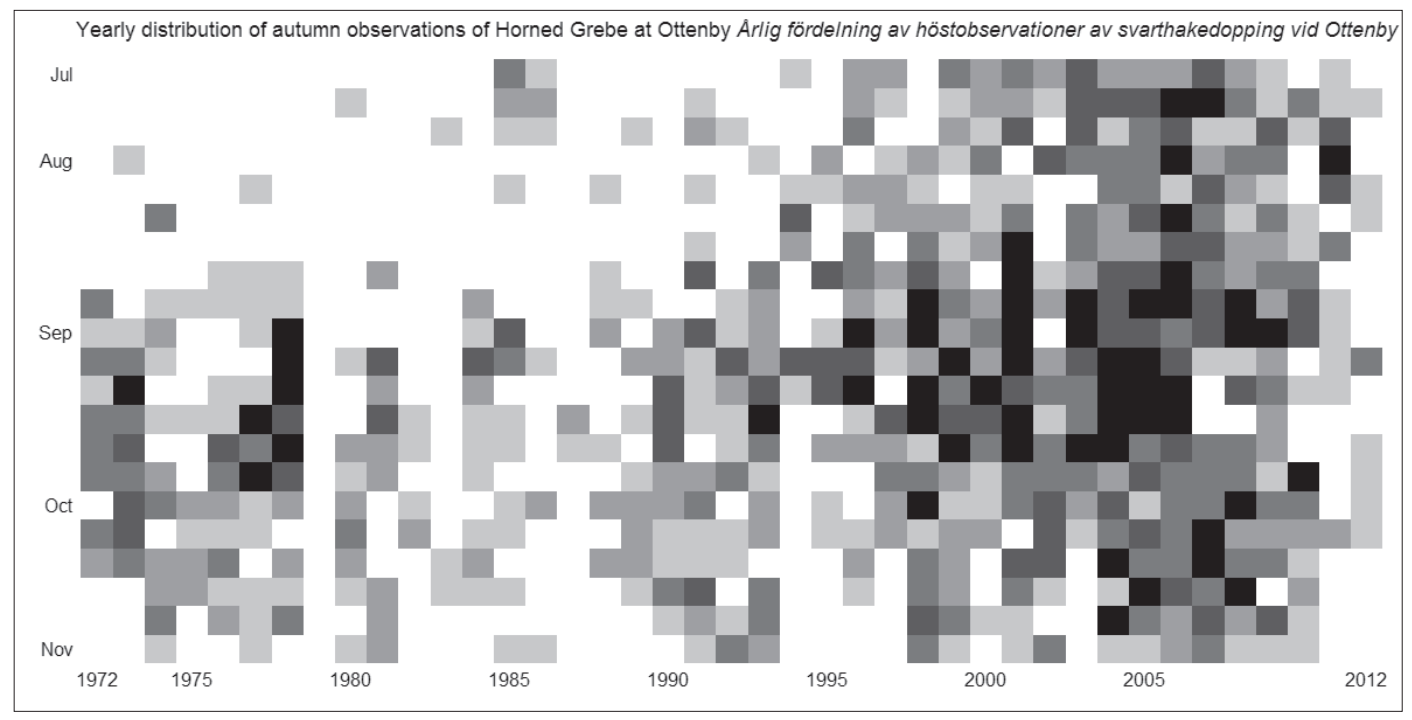

Figure 5. Schematic presentation of days with observations of Horned Grebe at Ottenby in autumns 1972 to 2012. Each square represents five-day periods between 25 July - 15 November and the six different colours (white to black) illustrate the number of days (0-5) with observations for each five-day period.

En schematisk presentation av dagar med observationer av svarthakedoppingar vid Ottenby under vårarna 1972 till 2012. Varje ruta representerar en femdagarsperiod mellan 25 juli - 15 november och de sex olika färgerna (vitt till svart) illustrerar antalet dagar (0-5) med observationer för varje femdagarsperiod.

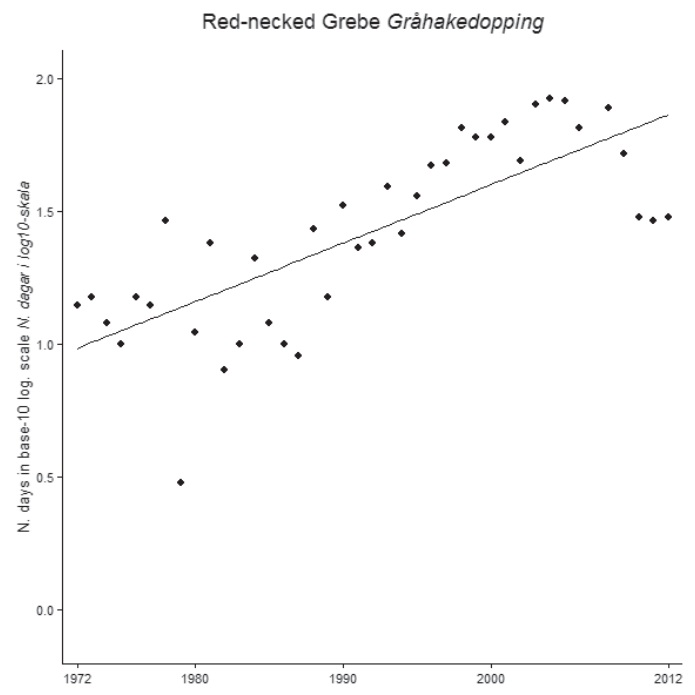

Figure 6. Annual number of days when Red-necked Grebe is observed at Ottenby between 1972 and 2012 presented with $\log 10$ scale. The line represents a linear regression $\mathrm{t}(39)=$ 7.47, $\mathrm{p}<0.001$, Adj. $\mathrm{R}^{2}=0.58$.

Antalet dagar per år då gråhakedopping har observerats vid Ottenby mellan 1972 och 2012 här presenterat med log10skala. Linjen representerar en linjär regression $t(39)=7,47$, $p<0,001$, Adj. $R^{2}=0,58$. rope and the number of days the two grebes were observed at Ottenby in the subsequent year during the period 1972-2012 (Horned Grebe: $\mathrm{t}_{(39)}=-0.63$, $\mathrm{p}=0.53$, Adj. $\mathrm{R}^{2}=-0.02$; Red-necked Grebe: $\mathrm{t}_{(39)}=$ $-1.50, \mathrm{p}=0.14$, Adj. $\mathrm{R}^{2}=0.03$, Figure 9). Most of the severest winters were found in the 1980 s, coinciding with the suggested low-point of the Swedish population of Horned Grebe. However, except for the winters 1979 and 1982, no direct decrease was recognized for years following a harsh winter. For example, in 1996, the number of days with observations increased after the severe winter.

\section{Discussion}

\section{Horned Grebe}

The estimate of 2000 pairs of Horned Grebe in Sweden in 2011 implies an increase from about 1200 pairs in 1996 and a return towards the estimates of about 2200 pairs in 1972 (Regnell 1981b, Douhan 1998). When comparing the results with the two earlier surveys on a regional level the numbers in 2011 for Götaland and Svealand were at least 30\% higher than in 1996 (Table 3). The increase in Svealand was almost 200\% from 1996 and was mainly due to increases in Uppland and 


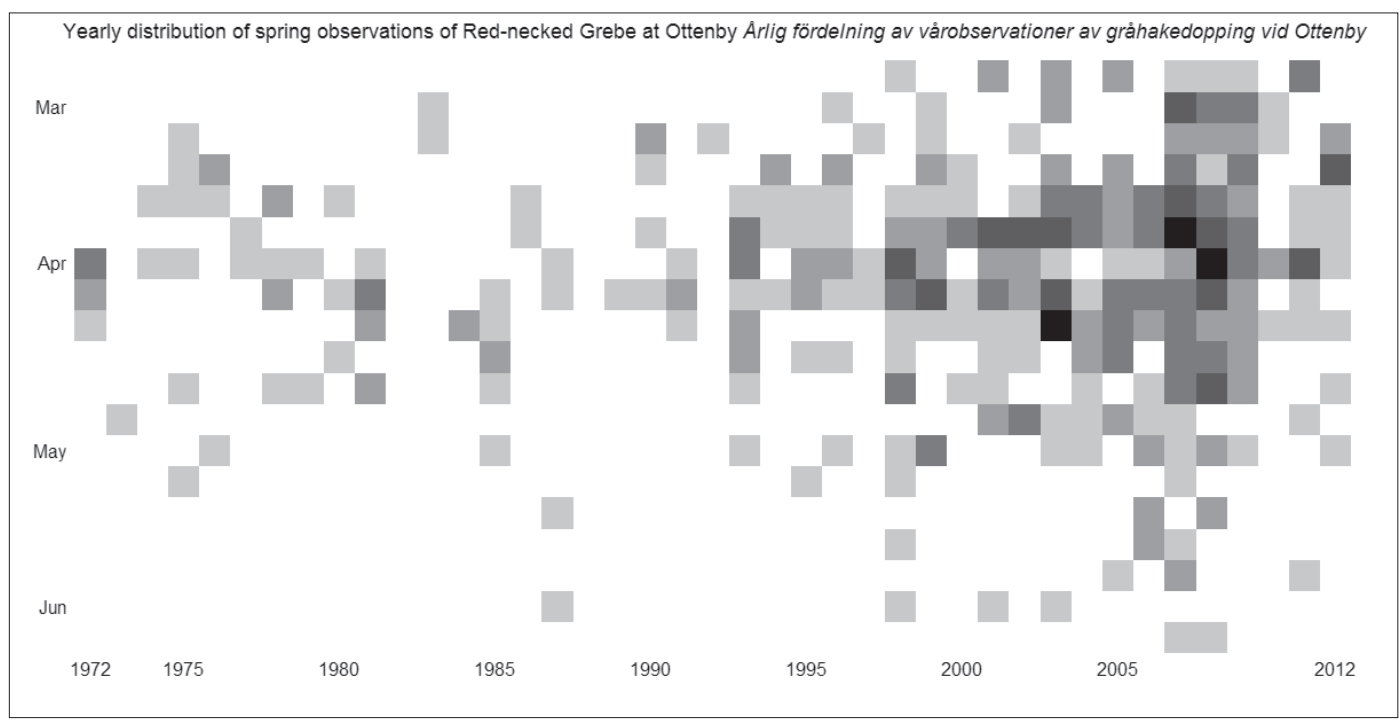

Figure 7. Schematic presentation of days with observations of Red-necked Grebe at Ottenby in springs 1972 to 2012. Each square represents five-day periods between 15 Mars - 15 June and the six different colours (white to black) illustrate the number of days (0-5) with observations for each five-day period.

En schematisk presentation av dagar med observationer av gråhakedoppingar vid Ottenby under vårarna 1972 till 2012. Varje ruta representerar en femdagarsperiod mellan 15 mars - 15 juni och de sex olika färgerna (vitt till svart) illustrerar antalet dagar (0-5) med observationer för varje femdagarsperiod.

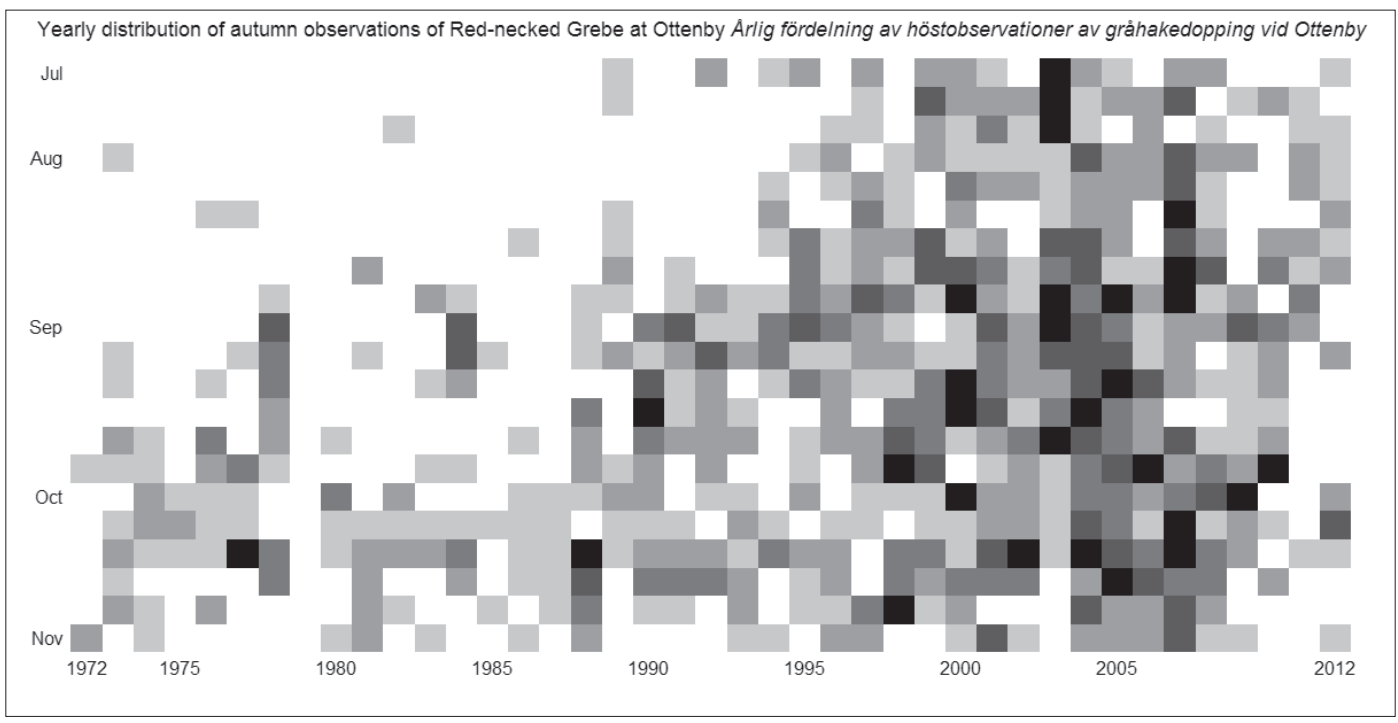

Figure 8. Schematic presentation of the days with observation of Red-necked Grebe at Ottenby in autumns 1972 to 2012 . Each square represents five-day periods between 25 July - 15 November and the six different colours (white to black) illustrate the number of days (0-5) with observations for each five-day period.

En schematisk presentation av dagar med observationer av gråhakedoppingar vid Ottenby under vårarna 1972 till 2012. Varje ruta representerar en femdagarsperiod mellan 25 juli-15 november och de sex olika färgerna (vitt till svart) illustrerar antalet dagar (0-5) med observationer för varje femdagarsperiod. 


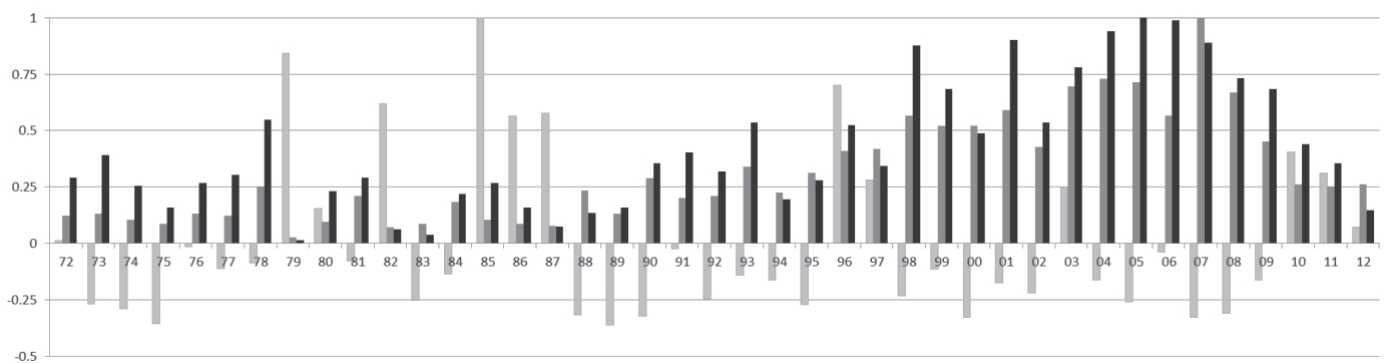

Figure 9. Total number of observation days per year at Ottenby, with maximal number of observation days set to " 1 " (Rednecked Grebe in dark grey, Horned Grebe in black). In medium grey is the PC1 of the Hellman index for Northern Europe for the preceding winter (see text for method); higher values illustrate more severe winters and lower values milder winters. Totalt antal dagar med observationer av gråhakedopping (mörkgrå staplar) och svarthakedopping (svarta staplar) med maximalt antal dagar för respektive art satt till "1". I mellangrått syns PC1 för Hellmanns index för norra Europa under föregående vinter (se metod för beskrivning) där höga värden representerar kallare vintrar och lägre värden mildare vintrar.

Södermanland, where the numbers had returned to the estimates of 1972. In Västmanland, in contrast, the values of 2011 did not recover to the same degree, and even though the species was poorly surveyed both in 1972 and in 2011, that is not likely the only explanation. In Norrland, trend evaluation was only possible for three provinces. Gästrikland and Medelpad showed an increase with at least $30 \%$ compare to 1996 , while no obvious change in numbers was recorded in Hälsingland. The recorded numbers of Horned Grebe in Gästrikland had increased considerably also compared to the estimates made in 1972. Compared to 1972 the population decline was less than $10 \%$ in Svealand and at least $10 \%$ in Götaland. The observational data from Ottenby showed similar patterns in numbers over the study period. The species had gone from a rare to a rather regular bird at Ottenby during the first half of the autumn season which may indicate an increase particularly of the number of birds in the local (Swedish) population. This was also what has been seen in provinces where birds, likely to migrate via Ottenby, have shown increases in breeding numbers, like for example in Gotland, Östergötland, Södermanland and Uppland. The numbers on Öland had on the other hand decreased over the study period and has probably not been involved in the late positive trend seen at Ottenby. Of the 11 provinces where survey efforts and data allowed trend evaluation, numbers had increased with $30 \%$ or more in seven since 1996 , while numbers were more or less stable in the other four. When the same comparisons were made with the survey in 1972, the corresponding picture was three and one provinces respectively, while two held numbers at least $30 \%$ lower than 1972. It is further clear that the centre of the Swedish population had moved further east, with Gotland, Södermanland, Uppland, Gästrikland and Västerbotten holding the greatest proportion of birds.

Among the neighbouring countries, Finland holds a fairly large population (Väisänen et al. 2011). The Finnish population of Horned Grebes had decreased in numbers and distribution between the two Bird Atlas surveys (1974-1989 and 2006-2010) to an estimated population of 1200 1700 pairs, with major decreases of the southern and central inlands, and local increases along the south-west and west coasts (Väisänen et al. 2011). Horned Grebe only breeds temporarily in Denmark (Grell et al. 1999). The Norwegian birds belong to the North Atlantic population, believed to have a low exchange with the Swedish birds (Fjeldså 1994). The Norwegian population was surveyed in 2007 and found to have increased slightly since the mid-1980s (Oien et al. 2008).

\section{Red-necked Grebe}

The Swedish population of Red-necked Grebe, in 2011 estimated to about 1300 pairs, has three strongholds in the country: Norrbotten/Västerbotten, Västergötland and Skåne. In the north, the numbers were likely to be about the same in 2011 as in the 1990s. Further south, the breeding numbers of Red-necked Grebe had increased steadily since 1996, in particular in Skåne and Västergötland (Bengtsson 2011, Hedberg Fält 2012). In Västergötland, the increase can be coupled to restoration efforts conducted in Lake Hornborga in the last two decades. While the area of open water has been enlarged in the basin the number of Red- 
Table 3. A comparison between estimated numbers of Horned Grebe in the three national surveys together, with an estimate of survey accuracy $(*=$ poor, $* *=$ medium, $* * *=$ good $)$. Where the numbers are sufficiently high and the measure of accuracy is medium or good, the trend between current survey and each of the two former is illustrated, where "--." = at least $30 \%$ decrease, "-" = at least $10 \%$ decrease, "=" = less than $10 \%$ change, "+" = at least $10 \%$ increase, and "++" = at least $30 \%$ increase. The "?" means that a trend could not be estimated. The estimated accuracy for the two former surveys is based on the described approach along with a judgement of the discrepancy between the reported and suggested number for each province within each report (Regnell 1981b; Douhan 1998).

En jämförelse mellan skattade antal svarthakedoppingar $i$ de tre nationella inventeringar, med angivna precisionsmått ("prec.", * = dålig, ** = måttlig, *** = god). Där data och precision tillåter presenteras populationsutvecklingen från de båda tidigare inventeringarna till den aktuella ("--" = minst $30 \%$ minskning, "'-" minst $10 \%$ minskning, " = " = mindre än $10 \%$ förändring, "'+" = minst $10 \%$ ökning, "++" = minst $30 \%$ ökning. Frågetecknet "? '” betyder att trenden inte har skattats. Den skattade precisionen för de två tidigare inventeringarna baseras på beskrivna tillvägagångssätt och en tolkning av skillnaden mellan rapporterade och skattade häckningsnumerärer för respektive landskap i respektive rapport.

\begin{tabular}{|c|c|c|c|c|c|c|c|c|c|c|c|}
\hline & \multicolumn{3}{|c|}{1972} & \multicolumn{3}{|c|}{1996} & \multicolumn{3}{|c|}{2011} & \multirow[b]{2}{*}{$\begin{array}{c}\text { Trend } \\
\text { Trend } \\
(72-11)\end{array}$} & \multirow[b]{2}{*}{$\begin{array}{c}\text { Trend } \\
\text { Trend } \\
(96-11)\end{array}$} \\
\hline $\begin{array}{l}\text { Province } \\
\text { Landskap }\end{array}$ & $\begin{array}{l}\text { Est. nu } \\
\text { Skatta } \\
\text { min }\end{array}$ & $\begin{array}{l}\text { mber } \\
\text { antal } \\
\max \end{array}$ & $\begin{array}{l}\text { Acc. } \\
\text { Prec. } \\
\text { acc. }\end{array}$ & $\begin{array}{l}\text { Est. } \mathrm{n} \\
\text { Skatta } \\
\text { min }\end{array}$ & $\begin{array}{l}\text { mber } \\
\text { antal } \\
\max \end{array}$ & $\begin{array}{l}\text { Acc. } \\
\text { Prec. }\end{array}$ & $\begin{array}{l}\text { Est. n } \\
\text { Skatta } \\
\text { min }\end{array}$ & $\begin{array}{l}\text { mber } \\
\text { antal } \\
\text { Max }\end{array}$ & $\begin{array}{l}\text { Acc. } \\
\text { Prec. }\end{array}$ & & \\
\hline Gästrikland & 50 & 75 & $* *$ & 65 & 65 & $* * *$ & 190 & 215 & $* *$ & ++ & ++ \\
\hline Hälsingland & 300 & 375 & $*(\mathrm{a})$ & 140 & 140 & $* * *$ & 140 & 160 & $* * *$ & $?$ & $=$ \\
\hline Medelpad & 30 & 70 & $*$ & 35 & 40 & $* * *$ & 45 & 55 & $* *$ & $?$ & ++ \\
\hline Härjedalen & 2 & 5 & $*$ & 2 & 5 & $*$ & 30 & 50 & $*$ & $?$ & $?$ \\
\hline Jämtland & 90 & 125 & $*$ & 100 & 100 & $*$ & 100 & 200 & $*$ & $?$ & $?$ \\
\hline Ångermanland & 70 & 110 & $*$ & 115 & 130 & $* *$ & 120 & 180 & $*$ & $?$ & $?$ \\
\hline Västerbotten & 80 & 125 & $*(\mathrm{c})$ & 165 & 170 & $* * *$ & 150 & 220 & $*$ & $?$ & $?$ \\
\hline Norrbotten & 60 & 100 & $*(\mathrm{a})$ & 15 & 15 & $*$ & 10 & 20 & $*$ & $?$ & $?$ \\
\hline Lappland & 40 & 90 & $*$ & 50 & 50 & $*$ & 50 & 100 & $*$ & $?$ & $?$ \\
\hline Norrland & 722 & 1075 & (d) & 687 & 715 & & 835 & 1200 & & $?$ & $?$ \\
\hline Närke & 40 & 60 & *(a) & 10 & 10 & $* *$ & 45 & 55 & $* *$ & $?$ & ++ \\
\hline Södermanland & 150 & 175 & $*$ & 60 & 70 & $*$ & 210 & 250 & $* *$ & $?$ & $?$ \\
\hline Uppland & 225 & 275 & $*(b)$ & 80 & 85 & $* *$ & 210 & 250 & $* *$ & $?$ & ++ \\
\hline Västmanland & 125 & 150 & $*$ & 15 & 15 & $* *$ & 25 & 35 & $*$ & $?$ & $?$ \\
\hline Värmland & 10 & 15 & $* *$ & 10 & 15 & $* *$ & 15 & 20 & $* * *$ & ++ & ++ \\
\hline Dalarna & 10 & 20 & $* *(\mathrm{~b})$ & 20 & 25 & $*$ & 15 & 25 & $*$ & $?$ & $?$ \\
\hline Svealand & 560 & 695 & & 195 & 220 & & 520 & 635 & & $=$ & ++ \\
\hline Skåne & 2 & 5 & $* *$ & 1 & 3 & $* *$ & 0 & 0 & $* * *$ & $?$ & $?$ \\
\hline Blekinge & 2 & 5 & $* *$ & 1 & 2 & $* * *$ & 1 & 3 & $* *$ & $?$ & $?$ \\
\hline Småland & 200 & 275 & $*$ & 60 & 80 & $* *$ & 70 & 80 & $* *$ & $?$ & $=$ \\
\hline Öland & 45 & 55 & $* * *$ & 30 & 30 & $* * *$ & 25 & 35 & $* *$ & -- & $=$ \\
\hline Gotland & 45 & 50 & $* *(a)$ & 55 & 60 & $* * *$ & 210 & 250 & $* * *$ & ++ & ++ \\
\hline Halland & 0 & 0 & & 0 & 0 & & 0 & 0 & & $?$ & $?$ \\
\hline Bohuslän & 0 & 0 & & 0 & 0 & & 0 & 0 & & $?$ & $?$ \\
\hline Dalsland & 0 & 2 & $* *$ & 0 & 0 & $* *$ & 1 & 3 & $*$ & $?$ & $?$ \\
\hline Västergötland & 70 & 80 & $* *$ & 70 & 80 & $* * *$ & 60 & 70 & & $=$ & $=$ \\
\hline Östergötland & 250 & 275 & $* *$ & 50 & 50 & $* *$ & 90 & 110 & $* *$ & -- & ++ \\
\hline Götaland & 614 & 747 & & 267 & 305 & & 457 & 551 & & - & ++ \\
\hline Totalt & 1896 & 2517 & & 1149 & 1240 & & 1812 & 2386 & & $=$ & ++ \\
\hline
\end{tabular}

(a) Overestimate according to Douhan (1998), (b) underestimate according to Douhan (1998), (c) underestimate according to Olsson and Wiklund (1999), (d) underestimate according to SOF (2002) and Ottosson et al. (2012) 
necked Grebes has increased and more than $80 \%$ of the breeders in the province 2011 were found in the basin. A similar dramatic increase has been seen in Skåne in the same period, most likely linked to the increase in number of created wetlands in the province (Bengtsson 2011, Naturvårdsverket 2013). The positive trend of the Swedish population was also illustrated in the steady increase in numbers of observation-days at Ottenby. One may wonder from where the birds at Ottenby are recruited, since the site is unlikely to be affected by the recent increase in Skåne. Red-necked Grebes breeding in Norrland are suggested to winter in Norway and should therefore not pass Ottenby either (Follestad et al. 1986, Fjeldså 1994). More knowledge is needed in the non-breeding movements of the species. Along with the increase, the observations in the first half of the autumn have become regular, suggesting (as for the Horned Grebe) an increase in the local (Swedish) population. In the neighbouring countries, the species has increased steadily in Denmark over the past decades, from about $300-500$ pairs in the 1960 s to about $1500-2000$ pairs in the 2000 s. It is likely that this region has acted as a source to the population in southern Sweden (Grell et al. 1999). The Danish population was suggested to have been favoured by the increased extraction of peat in the second half of the 20th century, because this has resulted in increased numbers of artificial wetlands used as breeding habitats. Eutrophication of lakes and milder winters are other suggested explanations to the positive trend of Red-necked Grebe in Denmark (Grell et al. 1999). The population in Finland has been stable between the two Bird Atlas surveys (1974-1989 and 2006-2010) and estimated to 6000-8000 pairs, mainly distributed in the southern half of the country (Väisänen et al. 2011). The potential exchange between the Finnish population and the Red-necked Grebes in northern Sweden may indicate that the trend also in Norrland could be stable. In Norway, only a few breeding records exists (Artsdatabanken 2014) and the wintering population regularly seen along the Norwegian coast is suggested to breed in northern Sweden, Finland and further east (Follestad et al. 1986).

\section{Habitat use during breeding}

In tandem with the two species' recent positive trends in Sweden, water bodies directly influenced by humans seem to have become increasingly important as breeding habitat, in particular in the southern part of the country. This might be the result of 'Thriving wetlands', one of the 16 environmen- tal quality objectives established in 1999 (Swedish Environmental Protection Agency 2013), with the goal to increase the number of wetlands in Sweden. The area of established and restored wetlands has since then steadily increased up to 6700 hectares in 2010 as a direct effect of this quality objective with 5500 hectares in Götaland, 1200 in Svealand, but only 25 hectares in the southernmost provinces of Norrland (Naturvårdsverket 2013). This provides increased opportunities for water-birds such as the two grebes to breed succesfully. In Skåne the majority of the breeding Red-necked Grebes were found in the 1653 hectares of new or restored wetlands in the region (Bengtsson 2011). The rareness of this type of breeding habitat in Norrland may explain the small numbers of grebes found in artificial water bodies throughout the northern part of the country. An obvious concern about what this current shift to artificial water bodies might bring is that the breeding success may be directly coupled to the rate of establishment, and efforts put on management, of waters constructed by humans. The effects of this are hard to determine today, but would be of great interest if the initiatives in the assessment of wetlands in Sweden should alter in the future. Also in the northern part of the country a shift in the birds' choice of breeding habitat was seen, where breeding pairs were increasingly occurring in coastal areas, while becoming rarer in the inland. This was not a new trend, and has been noticed already in 1972 for the Horned Grebe, but the pattern has become more frequent until 2011 when prominent numbers of especially Horned Grebe were found to successfully breed in coastal areas. They seemed to show preference to bays rich in vegetation which through the eutrophication of the Baltic Sea during the latter half of the $20^{\text {th }}$ century have become an increasingly common habitat along the coasts of Sweden (Andersen et al. 2011). Whether the decrease of breeders of the inland in many parts of Norrland is a direct result of this pattern or if there are other factors acting negatively on the quality of the historical breeding habitats of the species' need further investigations.

\section{Winter harshness}

Even though a number of relatively harsh winters in the 1980 s coincide with the estimated low-point of the number of Horned Grebe in Sweden, winter harshness alone cannot explain shifts between subsequent years in the observations of the two species at Ottenby. Some severe winters were followed by an increase of the number of observation 
days, while some prominent decreases of observation days were preceded by milder winters. In the long run, the weather may still have an effect on the size of the population when periods of mild winters provide opportunities to a northerly advancement of the wintering distribution of the populations (Newton 1998). Shorter migration routes would in turn promote an allocation of energy from migration to subsequent breeding investments and increase the future recruitment into the population (Alerstam 1990, McNamara \& Houston 2008). In the Mallard Anas platyrhynchos, such a shift of winter distribution has been recognized through ringing recoveries of Swedish ringed birds (Gunnarsson et al. 2012).

\section{Considerations for future studies}

Singles of complete surveys results in estimates that act as coarse snapshots of the population size which when repeated in a similar manner may give indication of shifts or trends in population number (Sutherland 2006). However, except the actual size of the breeding population, the results from complete surveys are sensible to several factors related to the strategies used in the survey. A complete survey will rarely result in observations of all breeding pairs in the population in target but is rather an attempt in searching for as many birds as possible to be able to estimate the total number. Grebes are particularly difficult to survey due to their stratified distribution, with groups of pairs in some water bodies while they are missing in others. Further they are rather opportunistic so they probe potential breeding habitats and do seldom return to the same pond if failing preceding breeding season (Fjeldså 2004). One approach in solving this is to in beforehand evaluate the number of water bodies potentially carrying grebes and then randomly choose a number which can be thoroughly investigated. The ratio between number of breeding localities and water bodies surveyed may then be extrapolated to the total number of water bodies potentially carrying breeding grebes. So to avoid underestimation error, follow-ups of known breeding sites needs to be combined with a systematic search of new potential breeding waters. To further complicate population estimates the two species are here shown to have increased their use of the archipelagos along the Baltic Sea for breeding. Together with the logistical complications when surveying the vast stretches of the Baltic coast that potentially holds breeding grebes, come new challenges in finding and assessing the number of pairs in the sometimes overlapping and loosely colony forming groups of breeding grebes as have been found in this survey. Many of these underestimates have probably been compensated for here through the revaluations conducted in accordance with Regnell (1981a).

For species complicated and/or costly to survey during breeding it can be useful to combine the complete survey (giving a number estimate) with a method that may give an estimate in the trend over time. Here daily absence/presence data from Ottenby, a site along the migration route of Swedish grebes, have been used to estimate the trend of the two species. The number of days the two grebes have been observed at Ottenby is likely dependent on the amount of birds passing the area each year, as well as the average time each bird spent within visual range. This is likely linked to both population sizes as well as their average breeding success when family groups migrate with lower pace and tend to spend longer time at roosting sites (Fjeldså 2004). So, the measurement used here is not necessarily directly linked to the number of birds passing Ottenby, or to the size of the populations in the recruitment areas. Nevertheless, everything else being equal, the likelihood of observation will increase with the size of the population that passes. Some other important causes of variation in the counts at Ottenby are birding effort among the personnel, the quality of technical equipment, and the knowledge of distinguishing the two species. Birding effort probably has varied throughout the study period while knowledge and equipment quite likely have improved steadily. Additionally, weather, migration and observation conditions will affect the yearly numbers of observations but not the long-term trend. However, if climate change affects relevant survival conditions along the migration route, the relative time spent in different stopovers will in turn be affected. In the backwater of current technology leaps in the mapping of the routes of many migrating species, it will become possible to more accurate connect breeding and wintering ground together with the most important migration routes (Bridge et al. 2011). Hopefully, this will help tying long-term observation data from migration sites such as Ottenby more precisely to the birds' recruitment areas, as well as improving the efficiency in future conservation efforts on migratory birds. 


\section{Conclusion}

The Swedish population of the Horned Grebe has recovered from the negative trend between the national surveys 1972 and 1996 and was in 2011 estimated to about 2000 pairs, a trend also supported in the long-term dataset of observations at Ottenby. Red-necked Grebe was for the first time in 2011 subject to a national survey in Sweden, but based on data from local surveys an increase over the past decades to the about 1300 pairs found in 2011 was evident. This pattern was also seen in the observation series from Ottenby. In Götaland, both Horned Grebe and Red-necked Grebe were most common in artificial water bodies. The two species have most likely been positively affected by the increased number of restored and newly established wetlands in southern Sweden and the increase of Red-necked Grebes in especially Skåne and Västergötland has likely been influenced by the positive trend of the species in Denmark. In Norrland, on the other hand, particularly Horned Grebe has become increasingly more common in coastal habitats, while traditional natural inland waters have been abandoned. No statistically significant relationship could be found between the measure of winter harshness in the suggested wintering area in Northern Europe and the observations at Ottenby, but an indirect effect of the Swedish population by winter weather cannot be ruled out. The results in this paper show how large-scale surveys may be combined with basic long-term presence/absence data to reveal insights in numbers and trends in two secretive breeding birds.

\section{Acknowledgement}

This paper is based on the efforts of a large number of bird-watchers observing and reporting grebes in 2011. To all of them I am most grateful. With their valuable knowledge of the local area, members of the regional report committees have compiled the data and given further information to enable an as accurate estimate as possible of the local population numbers. They are: Per Aspenberg, Mats Axbrink, Kenneth Bengtsson, Ulf T. Carlsson, Bill Douhan, Per Flodin, Urban Grenmyr, Rolf G. Gustavsson, Magnus Hallgren, Peter Hedberg Fält, Linus Hedh, Martin Heinrich, Anders Helseth, Per Helttunen, Kurt Holmqvist, Ronny Johansson, Lage Johnsson, Magnus Köpman, Mattias Laisfeldt, Calle Ljungberg, Ulf Löfås, Marcus Nygårds, Christer Olsson, Thomas Pettersson, Håkan Rune, Johan Råghall, Per Smitterberg, Göran Storensten och
Mikael Åsberg. I would also like to thank all volunteers that have worked at Ottenby Bird Observatory throughout the years and contributed with their observations. Martin Green, Åke Lindström, Jonas Waldenström and two reviewers gave valuable comments on an earlier version of the manuscript. This is contribution no. 283 from Ottenby Bird Observatory.

\section{References}

Alerstam, T. 1990. Bird migration. Cambridge University Press, Cambridge.

Andersen, J. H., Axe, P., Backer, H., Carstensen, J., Claussen, U., Fleming-Lehtinen, V., Jarvinen, M., Kaartokallio, H., Knuuttila, S., Korpinen, S., Kubiliute, A., Laamanen, M., Lysiak-Pastuszak, E., Martin, G., Murray, C., Mohlenberg, F., Nausch, G., Norkko, A. \& Villnas, A. 2011. Getting the measure of eutrophication in the Baltic Sea: towards improved assessment principles and methods. Biogeochemistry 106: 137-156.

Artdatabanken 2013. "Artportalen: Rapportsystemet för fåglar.” http://www.artportalen.se/birds/.

Artsdatabanken 2014. "Rapportsystemet for fugler." http:// artsobservasjoner.no/fugler/.

Aspenberg, P. 2012a. Riksinventeringen av svarthakedopping i Gästrikland 2011. Fåglar $i$ X-län. 43: 80-91.

Aspenberg, P. 2012b. Riksinventeringen av gråhakedopping i Gästrikland 2011. Fåglar i X-län. 43: 92-96.

Axelsson, P. 1997. Gråhakedoppingen Podiceps grisegena i sydöstra Skåne 1987-1996. Anser 36: 184-202.

Bengtsson, K. 2011. Gråhakedoppingen i Skåne 2011. Anser 50: 6-12.

Bibby, C. J., Burgess, N. D., Hill, D. A. \& Mustoe, S. 2000. Bird Census Techniques. Academic Press, London.

BirdLife International. 2013. "Birdlife's Global Species Programme." Retrieved 29 April 2013, http://www.birdlife. org/datazone/species.

Bønløkke, J., Madsen, J. J., Thorup, K., Pedersen, K. T., Bjerrum, M. \& Rahbek, C. 2006. Dansk Trakfugleatlas. Rhodos.

Bridge, E. S., Thorup, K., Bowlin, M. S., Chilson, P. B., Diehl, R. H., Fleron, R. W., Hartl, P., Kays, R., Kelly, J. F., Robinson, W. D. \& Wikelski, M. 2011. Technology on the Move: Recent and Forthcoming Innovations for Tracking Migratory Birds. Bioscience 61: 689-698.

Carlsson, U. T. 2011. Svarthakedoppingen som häckfågel i Värmland 1997-2011 - samt något om artens utbredning i stort och dess häckningsbiologi. Värmlandsornitologen. 39: $32-42$.

Cramp, S. \& Simmons, K. E. L. 1977. Handbook of the birds of Europe, the Middle East, and North Africa: the Birds of the Western Palearctic. Oxford University Press, Oxford.

del Hoyo, J., Elliott, A. \& Sargatal, J. 1992. Handbook of the Birds of the World. Lynx Edicions, Barcelona.

Douhan, B. 1998. Svarthakedoppingen: en fågel på tillbakagång i Sverige. Vår Fågelvärd. 57: 7-22.

Durinck, J., Skov, H., Jensen, F. P. \& Pihl, S. 1994. Important marine areas for wintering birds in the Baltic Sea. Ornis Consult report. Ornis Consult Limited, København.

Edelstam, C. 1972. The Visible Migration of Birds at Otten- 
by, Sweden. Sveriges Ornitologiska Förening, Stockholm. Fjeldså, J. 1994. Horndykker Podiceps auritus. In Norsk fugleatlas. Gjershaug, J. O., Thingstad, P. G., Eldøy, S. \& Byrkjeland, S. Norsk Ornitologisk Forening, Klæbu.

Fjeldså, J. 2004. The Grebes. Oxford University Press, Oxford.

Flodin, P. 2012. Svarthakedoppingen i Sörmland 2011 - resultat från riksinventeringen. Det Sörmländska fågelåret: 82-89.

Follestad, A., Larsen, B. H. \& Nygård, T. 1986. Sjøfuglundersøkelser langs kysten av Sør- og Nord-Trøndelag og sørlige deler av Nordland 1983 - 1986. Viltrapport 41. Viltforskningen, Trondheim.

Fransson, T., Österblom, H. \& Hall-Karlsson, S. 2001. Svensk ringmärkningsatlas Vol. 1, Lommar-rovfåglar. Naturhistoriska Riksmuseet, Stockholm.

Gilissen, N., Haanstra, L., Delany, S., Boere, G. \& Hagemeijer, W. 2002. Numbers and distribution of wintering waterbirds in the Western Palearctic and Southwest Asia in 1997, 1998 and 1999. Results from the International Waterbird Census. Wetlands International Global Series, Wageningen.

Grell, M. B., Boesgaard, L. \& Iversen, M. M. 1999. Fuglenes Danmark. Dansk Ornitologisk Forening, København.

Grenmyr, U. 1984. Gråhakedoppingens Podiceps grisegena förekomst i norra Sverige. Vår Fågelvärd. 43: 27-34.

Gunnarsson, G., Waldenström, J. \& Fransson, T. 2012. Direct and indirect effects of winter harshness on the survival of Mallards Anas platyrhynchos in northwest Europe. Ibis 154: 307-317.

Hedberg Fält, P. 2012. Häckande doppingar i Hornborgasjön 2010. Pp. 21-25 in Biologiska undersökningar $i$ Hornborgasjön 2010. Meddelande nr 41 från Hornborgasjöns fältstation/Hornborga-dokument $\mathrm{nr}$ 46. Länsstyrelsen $\mathrm{i}$ Västra Götalands län.

Hjort, C. \& Lindholm, C. G. 1978. Annual bird ringing totals and population fluctuations. Oikos 30: 387-392.

Ijnsen, F. 1988. Het karakterisieren van winters. Zenit 15: 50-58.

IUCN 2012. "The IUCN Red List of Threatened Species Version 2012.2. “ Retrieved 30 April, 2013, http://www. iucnredlist.org.

Jensen, F. P. 1993. Fuglene i de danske farvande: Resultaterne af landsdaekkende optaellinger 1987-91. Naturstyrelsen, Kobenhavn.

Johansson, R. 2012. Svarthakedoppingen i Kronoberg län Riksinventeringen 2011. Milvus - Fåglar i Småland. 41: 4-6.

Lindström, Å. \& Green, M. 2013. Monitoring population changes of birds in Sweden. Annual report for 2012. Department of Biology, Lund University, Lund.

McNamara, J. M. \& Houston, A. I. 2008. Optimal annual routines: behaviour in the context of physiology and ecology. Philosophical Transactions of the Royal Society B-Biological Sciences 363: 301-319.

Naturvårdsverket 1997. Skötselplan för Hornborgasjöns naturreservat. Länstyrelsen i Skaraborgs län.

Naturvårdsverket. 2013, 2012-06-05. "Miljömål." Retrieved 1 August 2013, http://www.miljomal.se/Miljomalen/Alla-indikatorer/Indikatorsida/?iid= $8 \& \mathrm{pl}=1$.

Newton, I. 1998. Population Limitation in Birds. Academic Press, San Diego.

Nygårds, M. 2011. Svarthakedopping och gråhakedopping i
Östergötland 2011. Vingspegeln. 30: 122-127.

Oien, I. J., Aarvak, T. \& Reinsborg, T. 2008. Slavonian grebes in Norway - an endangered species on the increase? Vår Fuglefauna 31: 20-27.

Olsson, C. \& Wiklund, J. 1999. Västerbottens fåglar. Västerbottens Ornitologiska Förening, Umeå.

Ottosson, U., Ottvall, R., Elmberg, J., Green, M., Gustafsson, R., Haas, F., Holmqvist, N., Lindström, A., Nilsson, L., Svensson, M., Svesson, S. \& Tjernberg, M. 2012. Fåglarna i Sverige - antal och förekomst. Sveriges Ornitologiska Förening, Halmstad.

R Core Team 2013. R: A language and environment for statistical computing. R Foundation for Statistical Computing, Vienna, Austria.

Regnell, S. 1981a. Att taxera häckningsbestånd av svarthakedopping Podiceps auritus. Vår Fågelvärld. 40: 33-46.

Regnell, S. 1981b. Häckningsbeståndet av svarthakedopping Podiceps auritus i Sverige. Vår Fågelvärld. 40: 23-32.

Saurola, P., Valkama, J. \& Velmala, W. 2013. The Finnish Bird Ringing Atlas. The Finnish Museum of Natural History, Helsinki.

Sauter, A., Korner-Nievergelt, F. \& Jenni, L. 2010. Evidence of climate change effects on within-winter movements of European Mallards Anas platyrhynchos. Ibis 152: 600609.

SOF 2002. Sveriges fåglar. Sveriges Ornitologiska Förening, Stockholm.

Sonntag, N., Garthe, S. \& Adler, S. 2009. A freshwater species wintering in a brackish environment: Habitat selection and diet of Slavonian grebes in the southern Baltic Sea. Estuarine Coastal and Shelf Science 84: 186-194.

Stone, C. J., Webb, A., Barton, C., Ratcliff, N., Reed, T. C., Tasker, M. L., Camphuysen, C. J. \& Pienkowski, M. W. 1995. An atlas of seabirds distribution in north-west European waters. Joint Nature Conservation Committee, Petersborough.

Sundström, T. \& Olsson, C. 2005. Västerbottens kustfågelfauna - Inventering av kustfågelbestånden 2001/2002. Länstyrelsen i Västerbotten.

Sundström, T. \& Olsson, C. 2009. Norrbottens kustfågelbestånd - inventering 2007 och 2008. Länstyrelsen i Norrbotten 2009:5.

Sutherland, W. J. 2006. Ecological Census Techniques. Cambridge University Press, Cambridge.

Swedish Environmental Protection Agency. 2013. "The National Environmental Objectives." Retrieved 1 August 2013, http://www.swedishepa.se/Environmental-objectives-and-cooperation/Swedens-environmental-objectives/ The-national-environmental-objectives/Thriving-Wetlands/.

Väisänen, R. A., Hario, M. \& Saurola, P. 2011. “Population estimates of Finnish birds." The Third Finnish Breeding Bird Atlas (eds. Valkama, J., Vepsäläinen, V. \& Lehikoinen, A.). Finnish Museum of Natural History and Ministry of Environment. Retrieved 13 June 2013, http://atlas3.lintuatlas.fi/english/. 


\section{Sammanfattning}

Genom att med jämna mellanrum registrera storleken på en population är det möjligt att följa dess status och trend. Vanliga sätt att inventera fåglar är nationella punkt- eller linjerutter, standardiserad ringmärkning eller systematisk räkning av fåglar längs flyttleder. Vissa arter är dock så pass fåtaliga att de kräver andra tillvägagångssätt. Två sådana arter är svarthakedopping Podiceps auritus och gråhakedopping Podiceps grisegena. För att öka kunskapen om de båda arternas förekomst i landet lät Sveriges Ornitologiska Förening (SOF) göra ett upprop inför 2011 års häckningssäsong där fågelskådare och lokala fågelföreningar fick till uppgift att undersöka fåglarnas förekomst i sina närområden. Gråhakedoppingen har inte tidigare varit föremål för en nationell inventering i SOFs regi medan svarthakedoppingen har inventerats två gånger (Regnell 1981b, Douhan 1998). Första gången det begav sig var 1972 då den svenska populationen skattades till omkring 2200 par. Nästa gång arten inventerades, 1996, hamnade summan på ca 1200 par. Här presenteras nu både genomförandet och resultaten från 2011 års inventering tillsammans med observationer kring fåglarnas habitatsval. Därtill jämförs resultaten med långtidserier av observationsdata från Ottenby fågelstation i ett försök att göra en samlad bedömning av arternas utveckling och status i landet. Slutligen diskuteras temperaturförhållanden i övervintringsområden samt senare tiders åtgärder i svenska våtmarker som två möjliga faktorer som påverkar doppingarnas överlevnad och häckningsframgång.

Svarthakedopping och gråhakedopping är två medelstora dykande fågelarter med förkärlek till småvatten som grunda sjöar och reservoarer. Medan svarthakedoppingen trivs i små eutrofa sjöar och tjärnar i barrskogsregionen förknippas gråhakedoppingen vanligen med slättsjöar på lite sydligare breddgrader. Arternas övervintringsområden i Europa överlappar rejält och fåglarna kan vintertid påträffas från Nordsjön söderut till Medelhavet. Dock förekommer koncentrationer av gråhakedoppingar i danska vatten samtidigt som en viktig övervintringsplats för svarthakedoppingar återfinns i södra Östersjön. Arternas häckningsområden i Sverige överlappar betydligt i landets sydöstra och nordöstra del samtidigt som de båda allt oftare påträffas i samma typ av konstgjorda småvatten. Medan den svenska populationen av gråhakedopping har uppfattats som ökande har svarthakedoppingen visat tecken på återhämtning från artens noterade bottenår.
Inför 2011 års häckningssäsong uppmanade SOF landets fågelskådare och lokala fågelföreningar att medverka $i$ en nationell inventering av de båda arterna. Potentiella häckplatser skulle besökas minst en gång i sökandet efter revirhävdande eller spelande doppingar, vilket var de avgörande häckningskriterierna. Resultaten sammanställdes sedan lokalt av de regionala rapportkommittéerna för att sedan skickas till undertecknad för den nationella sammanställningen. För att översiktligt presentera omfattningen av de lokala inventeringsinsatserna, och därigenom få ett mått på precisionen på efterföljande numerära uppskattningar, delades de lokala inventeringsresultaten in i tre grupper. De inventeringar som genomförts enligt instruktionerna eller på annat sätt kunde presentera tillförlitliga uppskattningar av de lokala bestånden hamnade $\mathrm{i}$ grupp A. B-gruppen bestod av områden med sämre täckning men där kunskapen om de båda doppingarna kunde hämtas från andra nyligen genomförda inventeringar. I grupp C hamnade slutligen de områden där de numerära uppskattningarna var mindre väl underbyggda eller där aktuella beståndsuppskattningar helt saknades. I ett försök att uppskatta numerären i grupp $\mathrm{C}$ hämtades information från den spontana inrapporteringen av arterna till de regionala rapportkommittéerna, historiska inventeringar i området och information från intilliggande landskap. Baserat på informationen om inventeringsinsatsen gjordes sedan en uppskattning av de lokala bestånden, inklusive ett mått på precisionen av densamma. Precisionen mättes från god $(* * *)$ till dålig $(*)$ baserat på informationen beskriven ovan. För att bli jämförbar med resultatet från tidigare nationella inventeringar av svarthakedoppingen så presenteras resultaten per landskap. När det gäller mer generella beskrivningar refereras till Götaland, Svealand och Norrland (Figur 1).

Tillsammans med fågelobservationerna ombads inventeraren att i korta ordalag redogöra för vilken typ av vatten som doppingarna påträffades i. Vid den slutliga sammanställningen arrangerades denna habitatsinformation i fyra grupper som i grova drag beskriver den allmänna preferensen hos doppingar påträffade under 2011 års inventering. De fyra grupperna var följande:

Naturliga inlandsvatten: Vatten som inte avsiktligt har modifierats av människor, exempelvis skog- och slättsjöar samt tjärnar. Konstgjorda vatten: Bevattningsdammar och anlagda vatten intill gårdar och golfbanor, liksom naturliga vatten som har varit föremål för omfattande restaureringsåtgärder, exempelvis Hornborgasjön och Tåkern. Kust: Fåglar som häckar i vikar och småöar längs Öster- 
sjön. Här kan det ibland förekomma häckningar i anslutning till utlopp från floder och älvar. Övrigt: Enstaka häckande par som påträffats i andra habitat eller där habitatet på något sätt är intermediärt de ovanstående habitaten.

Ottenby, beläget på Ölands södra udde $\left(56^{\circ} 12^{\prime} \mathrm{N}\right.$, $16^{\circ} 24^{\prime} \mathrm{E}$ ), är känt för sin rikedom på både rastande och flyttande fåglar. På Ottenby fågelstation har personalen på daglig basis fört anteckningar över vilka arter som observerats i närområdet. Från starten av den standardiserade fångsten, 1972, finns information från perioderna 15 mars - 15 juni och 25 juli - 15 november för samtliga år. Säsongsvisa summeringar (vår respektive höst) av dessa observationstillfällen gjordes och sammanställdes för perioden 1972 - 2012 .

Genom att använda dagsmedeltemperaturer hämtade från väderstationer i Rotterdam (Nederländerna), Vestervig (Danmark), Falsterbo (Sverige), Rostock och Angermunde (båda belägna i Tyskland) togs ett mått fram på temperaturförhållandena i doppingarnas förmodade övervintringsområde. Ett Hellmann index räknades ut genom att summera det absoluta värdet av samtliga negativa dagmedeltemperaturer under perioden december - februari för respektive station. I efterföljande PCA-analys förklarade den första principiella komponenten (PC1) 93.3\% av variationen. Denna användes därför som en generellt mått på vinterförhållandena i norra Europa.

Den svenska populationen av svarthakedopping skattades till ca 2000 par (intervall 1812-2386, Tabell 1). Majoriteten av de 835-1200 paren i Norrland återfanns i kustlandskapen. Det var endast Gästrikland, Hälsingland och Medelpad som blev relativt väl inventerade så numerären i övriga norrländska landskap är mer osäkra. I Svealand skattades populationen till 520-635 par medan numerären i Götaland landade på 457-551 par. Arten var talrikast längs östersjökusten, mer sällsynt $\mathrm{i}$ landets västligare delar och saknades nästan helt i de sydvästligaste landskapen.

Antalet gråhakedoppingar skattades till 1300 par (intervall 1109-1680, Tabell 2). De 384-775 paren i Norrland var huvudsakligen extrapoleringar av data från tidigare inventeringar vilket bör tas $\mathrm{i}$ beaktning när siffrorna tolkas. Arten var relativt sällsynt i Svealand med endast 89-117 par, där majoriteten återfanns i Uppland. I Götaland skattades populationen till 636-788 par. Fåglarna i södra Sverige var relativt jämt utspridda, förutom i Västergötland och Östergötland där Hornborgasjön och Tåkern höll betydande delar av totalsumman.

Fördelningen av de habitat som doppingarna påträffades i under inventeringen skiljde sig både mellan de båda arterna och mellan landets regioner. Majoriteten av de häckande fåglarna av båda arterna i Götaland återfanns i konstgjorda inlandsvatten (Figur 2). I Svealand återfanns över $50 \%$ av gråhakedoppingarna i naturliga inlandsvatten medan svarthakedoppingen mer regelbundet påträffades $i$ konstgjorda inlandsvatten. De båda arterna var relativt jämt fördelade mellan kusten och naturliga inlandsvatten i Norrland. Några få procent av de norrländska svarthakedoppingarna återfanns dock i konstgjorda inlandsvatten medan gråhakedoppingen helt saknades i den gruppen av habitat.

Medan antalet dagar med observationer av svarthakedopping vid Ottenby har varierat kraftigt under perioden 1972-2012 med en svacka under 1980-talet och en topp i början av 2000-talet så var antalet dagar med arten i början och slutet av perioden väldigt lika (Figur 3). Samtidigt som arten blev allt mer frekvent $\mathrm{i}$ fågelstationens dagboksanteckningar från 1990-talet och framåt så ökande andelen observationer gjorda under första halvan av hösten (Figur 4 och 5).

Antalet observerade gråhakedoppingar vid Ottenby ökade under perioden 1972-2012 (Figur 6). Fram till mitten av 1990-talet var gråhakedoppingen knappt årlig under vårsäsongerna (Figur 7) och huvudandelen av dagarna med observationer under både vår och höst var från andra halvan av studieperioden. Samtidigt har arten blivit allt vanligare under den första delen av hösten (Figur 8).

Inget signifikant förhållande kunde hittas mellan den årliga variationen i vintertemperatur och antalet dagar som de båda doppingarna har observerats vid Ottenby efterföljande år under perioden 1972-2012 (Figur 9). De flesta år med hårda vintrar inföll under 1980-talet och sammanföll med perioden med låga antal dagar med observationer av svarthakedopping vid Ottenby. Däremot var det endast vintrarna till 1979 och 1982 som efterföljdes av en direkt nedgång av antalet observationer av de båda arterna och för till exempel 1996 skedde en ökning av antalet observationsdagar av arterna efter en svår vinter.

Den svenska populationen av svarthakedopping 2011 skattades till ca 2000 par vilket indikerar en ökning från de ca 1200 paren 1996, men är färre än de 2200 par som uppmättes 1972. Antalet observationer vid Ottenby uppvisade liknande mönster under perioden samtidigt som arten tycktes ses mer frekvent under första halvan av hösten vilket indikerar att det var den svenska populationen som ligger bakom förändringarna. Det var också just bland de landskap som förväntas hålla svarthakedopping- 
ar som flyttar förbi Ottenby som antalet par hade ökat. Däremot hade den öländska populationen minskat under studieperioden och var förmodligen inte involverad i det ökade antalet observationer. Av de 11 landskap där det var möjligt att utvärdera förändringar mellan inventeringarna hade numerären ökat med minst $30 \%$ i sju av dem jämfört med 1996 medan de övriga fyra höll mer eller mindre stabila populationer. När samma jämförelse görs mot 1972 års inventeringsresultat var det tre landskap som uppvisade en ökning på minst $30 \%$, ett landskap höll samma numerär medan två landskap uppvisade en minskning på minst $30 \%$. Resultaten visar också att den svenska populationen av svarthakedopping har förskjutits mot öster med Gotland, Södermanland, Uppland, Gästrikland och Västerbotten som de viktigaste landskapen för arten. I våra grannländer är det Finland som håller den största populationen. Den finska populationen har minskat i antal och utberedning mellan de två atlasinventeringarna (1974-1989 och 2006-2010) till ca 1200-1700 par. Arten häckar endast tillfälligt i Danmark. De norska fåglarna tillhör den nordatlantiska populationen som antas ha ett lågt utbyte med den svenska populationen.

Den svenska populationen av gråhakedopping 2011 skattades till ca 1300 par och arten uppvisade tre starka fästen i landet. I norr var den fortfarande relativt vanlig i de båda kustlandskapen Västerbotten och Norrbotten medan den i söder hade blivit allt vanligare i framförallt Skåne och Västergötland. Samma positiva trend hittades också i antalet dagar med observationer av arten vid Ottenby. Precis som med svarthakedoppingen så hade antalet observationer av gråhakedoppingen blivit större under höstsäsongens första halva. I grannländerna har arten ökat stadigt i Danmark under de senaste decennierna från ca 300-500 par under 1960-talet till ca 1500-2000 par under 2000-talet och regionen kan ha fungerat som en källa till den växande sydsvenska populationen. Ökningen av den danska populationen har knutits samman med den ökade torvbrytningen i landet där fåglarna har frekventerat de småvatten som har bildats till följd av verksamheten. Den finska populationen av gråhakedopping har hållit sig stabil på 6000-8000 par mellan de båda atlasinventeringarna och beroende på utbytet mellan de finska och norrländska populationerna så skulle detsamma kunna gälla numerären i norra Sverige. Arten tycks endast häcka fåtaligt i Norge och de fåglar som uppehåller sig där vintertid antas främst komma från häckningsområdena $\mathrm{i}$ norra Sverige, Finland och österut.
I samband med de båda arternas sentida positiva trend i Sverige har vatten direkt påverkade av människan blivit ett allt mer viktigt häckningshabitat, framförallt i södra delarna av landet. Detta är antagligen ett resultat av ambitionen mot fler småvatten inom "Myllrande våtmarker", ett av Naturvårdsverkets 16 miljökvalitetsmål som etablerades 1999. Den totala ytan av nyetablerade eller restaurerade våtmarker har sedan dess stadigt ökat till 6700 hektar år 2010. Götaland (5500 hektar) höll den största ytan medan 1200 hektar fanns i Svealand. Norrland stod för 25 hektar och det var troligen bristen på denna typ av vatten i Norrland som förklarar de låga andelen häckfåglar i miljön i norra Sverige. En annan sorts habitatval har framförallt noterats i Norrland där arterna har minskat i de naturliga inlandsvattnen till förmån för kustmiljöerna. Fåglarna tycktes föredra vegetationsrika vikar vilket har blivit allt vanligt förekommande längs Sveriges kuster till följd av eutrofieringen av Östersjön under 1900-talets andra hälft.

Även om ett antal hårda vintrar sammanföll med populationsminimum hos de svenska svarthakedoppingarna under 1980-talet så kunde inte vinterförhållandena i sig förklara skillnaderna i observationsnumerär mellan efterföljande år vid Ottenby. I långa loppet kan vädret ändå ha en påverkan på populationsstorlekarna då perioder av milda vintrar ger utrymme för en nordlig förskjutning av övervintringsområdena. Detta skulle i sin tur leda till kortar flyttsträckor och därigenom möjligheter till en allokering av energibudgeten från migration till häckning och en ökning av rekryter till populationen.

När det genomförs totalinventeringar av diskreta arter som de båda doppingarna i så pass vidsträckta områden som Sverige kommer slutresultaten, trots högt ställda krav på genomförandet, generera uppskattningar förknippade med en viss osäkerhet. Utöver stor noggrannhet vid själva fältbesöket är det viktigt att tänka på hur urvalet av de potentiella häckningsplatserna går till samt att det sker en tydlig bokföring även vid de vatten som inte tycktes hålla någon dopping. Samtidigt bör man akta sig för att endast förlita sig till kända doppingvatten då arterna är opportunistiska till valet av häckningsplats. Något som däremot kan verka kompletterande till ögonblicksbilder av en fågelpopulation likt denna inventering är kontinuerlig stickprovsmätning över lång tid. Genom ett sådant arbetssätt kan en populationssumma knytas till en trend vilket tillsammans beskriver både status och utveckling, även för diskreta arter som de båda doppingarna. 